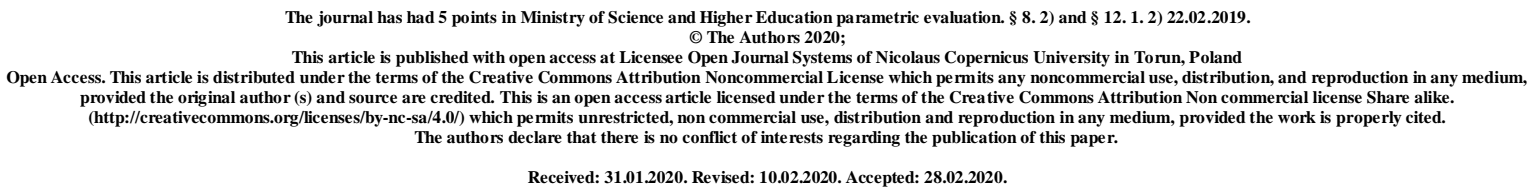

UDC 616-002.2-008.853-092.9:577.114.4

\title{
SUBSTANCE P BLOCKADE EFFECTS ON BONE MARROW HEMATOPOIESIS IN SECONDARY CHRONIC INFLAMMATION
}

\author{
O. M. Shevchenko, V. O.Sych
}

\section{Kharkiv National Medical University, Ukraine}

\section{Abstract}

Inflammation is defined by the features of bone marrow hematopoiesis. Thus, an objective of the study was to determine the substance $\mathrm{P}$ inhibition effects on bone marrow hematopoiesis in secondary chronic carrageenan-induced inflammation in experimental prospective controlled study on 132 white male WAG rats. On the background of blockade of substance $\mathrm{P}$, the course of inflammation was characterized by a less intense neutrophilic reaction and the development of the lymphocyte component at earlier stages of inflammation. Given the peculiarities of bone marrow hematopoiesis in carrageenan secondary chronic inflammation on the background of its suppression, the influence of substance $\mathrm{P}$ on the course of chronic inflammation is certain.

Key words: red bone marrow; rats; experiment; inflammation; substance $P$. 


\title{
ЕФЕКТИ БЛОКАДИ РЕЧОВИНИ Р НА КІСТКОВОМОЗКОВЕ КРОВОТВОРЕННЯ ЗА ВТОРИННОГО ХРОНІЧНОГО ЗАПАЛЕННЯ
}

\author{
О. М. Шевченко, В. О. Сич
}

\section{Харківський національний медичний університет, Україна}

Запалення визначається особливостями кровотворення кісткового мозку. Таким чином, метою дослідження було визначити вплив блокування речовини Р на гемопоез кісткового мозку за вторинного хронічного запалення, індукованого карагіненом у експериментальному проспективному контрольованому дослідженні на 132 білих щурах-самцях інбредної лінії WAG. На тлі блокади речовини Р перебіг запалення характеризувався менш інтенсивною нейтрофільною реакцією та розвитком лімфоцитарного компонента на більш ранніх стадіях запалення. Враховуючи особливості гемопоезу кісткового мозку за вторинного хронічного карагіненіндукованого запалення на фоні блокування впливу речовини Р, дозволяє стверджувати про ії причетність до визначення перебігу хронічного запалення.

Ключові слова: червоний кістковий мозок; щури; експеримент; запалення; субстанція $P$.

Background. Tachykinins are a group of protein neurotransmitters that are synthesized in almost all parts of the mammalian nervous system and play an important role in the processes of nervous excitation [1,2]. Moreover, tachykinins and their receptors are widely represented outside the nervous system: in the respiratory, cardiovascular, endocrine and immune systems, as well as in the skin and gastrointestinal tract [3]. The most studied tachykinins are substance $\mathrm{P}(\mathrm{SP})$, neurokinin A, neurokinin B, neuropeptide $K$, neuropeptide $\gamma$, chemokinin-1, cacitonin-gene bound peptide [1, 3, 4].

Substance $\mathrm{P}$ is one of the most studied tachykinins today. Its extract was first isolated in 1931 from the horse's brain and intestines in the form of a powder, hence its name (letter "P") comes from [3, 5]. Structurally, the SP consists of 11 amino acid residues synthesized on the ribosomes of many neural and extraneural cells, including immune. It is believed that SP plays a role in the etiology of depression and anxiety, vomiting, pain, asthma, psoriasis, inflammatory of different systems, including CNS, i. e. migraine and schizophrenia [6].

Substance $\mathrm{P}$ is released into the intercellular substance by exocytosis in vesicles and has a very short half-life, ranging from a few seconds to ten minutes, depending on physicochemical conditions [7]. 
Exocytosis occurs only after an increase in the concentration of intracellular calcium [8,9], which enters either through plasmalemic channels or through the channels of the mitochondrial membrane.

The state of bone marrow hematopoiesis is one of the criteria for the presence and nature of the inflammatory process, and can also serve as a sign to assess the effectiveness of anti-inflammatory therapy, as the blood system is a crucial system of inflammation. This determines the expediency of the study of bone marrow hematopoiesis on the background of blockade of inflammatory mediators, in particular, the substance $\mathrm{P}$.

Thus, the study of bone marrow hematopoiesis under the conditions of inhibition of substance $\mathrm{P}$ can provide integrative answers to questions about the role and receptor mechanisms of tachykinins in the pathogenesis of inflammation.

Objective of the study: to determine the features of bone marrow hematopoiesis in carrageenan secondary chronic inflammation on the background of its suppression by the introduction of the NKR-1 blocker substance $\mathrm{P}$.

Material and methods of research. An experimental prospective controlled randomized study was performed on 132 white male WAG rats weighing 180-200 g. A carrageenan model was selected, $10 \mathrm{mg}$ of $\alpha$-carrageenan (Sigma, USA) in $1 \mathrm{ml}$ of saline was administered intramuscularly to the rat thigh under conditions of thiopental anesthesia [11]. To inhibit the synthesis and effects of substance P, an NK-1 receptor inhibitor aprepitant was used, which was administered intraperitoneally at a dose of 10 $\mathrm{mg}$ dissolved in $1 \mathrm{ml}$ of isotonic sodium chloride solution, daily throughout the experiment [12]. Stratification of animals in separate series of the experiment (for 6 hours and for 1, 2, 3, 5, 7, 10, 14, 21, 28 days) was carried out in accordance with the objectives of the study in the amount of 6 individuals. The red bone marrow of the femur was used as a material for the study.

Assessment of bone marrow hematopoiesis was performed according to the characteristics of the cellular composition of the bone marrow from femur. Bone marrow was obtained by isolating the rat femur, dissecting from soft tissues, washing the bone marrow canal with a solution of acetic acid $3 \%-1$ $\mathrm{ml}$, preparation of smears-micropreparations. Cell counting was performed in Goryaev's chamber. Bone marrow smears were prepared by squeezing it from the distal end of the dissected femur onto a glass slide and diluting it with homogeneous serum, followed by fixation in ethyl alcohol and azure staining with II-eosin according to Romanowski-Giemsa. Absolute total myelokaryocytes and subpopulations were assessed by red bone marrow microscopy.

A preliminary assessment of the nature of the distribution of indicators by visual method and using the Shapiro-Wilk W test revealed that it differs significantly from normal; this prompted the further use of non-parametric statistics. Then, to analyze the quantitative indicators to characterize the central pattern and variability of traits in the groups of subjects, the median (Me) and the quartile interval were 
calculated with the values of the lower, $25 \%$ quartile (LQ) and upper, $75 \%$ quartile (UQ), the result was expressed in the format of "Me [LQ; UQ]". The probability of differences in the independent groups was assessed using the Mann-Whitney U-test. Qualitative indicators were described in absolute and relative (percentage) values. Comparison of the two groups on a qualitative basis was performed by angular transformation of Fisher with the value of the empirical angle $\varphi$ more than two groups - by constructing conjugacy tables, followed by the method of maximum likelihood of the criterion "chi-square" $\left(\chi^{2}\right)$. In all statistical calculations, the threshold value of the significance level $p$ was selected as 0.05 . In the case of multiple comparisons, the Bonferoni correction was used (the product of the threshold value p 0.05 and the number of comparisons was taken as the critical value p). Maintenance of the research data bank, basic calculations of derivative indicators, frequency characterization of characteristics, construction of diagrams were performed using Microsoft Excel 2019, all calculations were performed using Statsoft Statistica 12.

Results and discussion. Under the conditions of the natural course of inflammation, a wavy nature of the changes was established, which indicates selective shifts in bone marrow hematopoiesis of various subpopulations of cells, both in the direction of amplification and suppression (Table 1).

It was of interest to make a comparative characterization of the dynamics of individual cell populations as the duration of inflammation increases during its natural course and on the background of blockade of substance $\mathrm{P}$.

The total number of myelokaryocytes compared to the control shows a stable upward trend (Fig. 1).

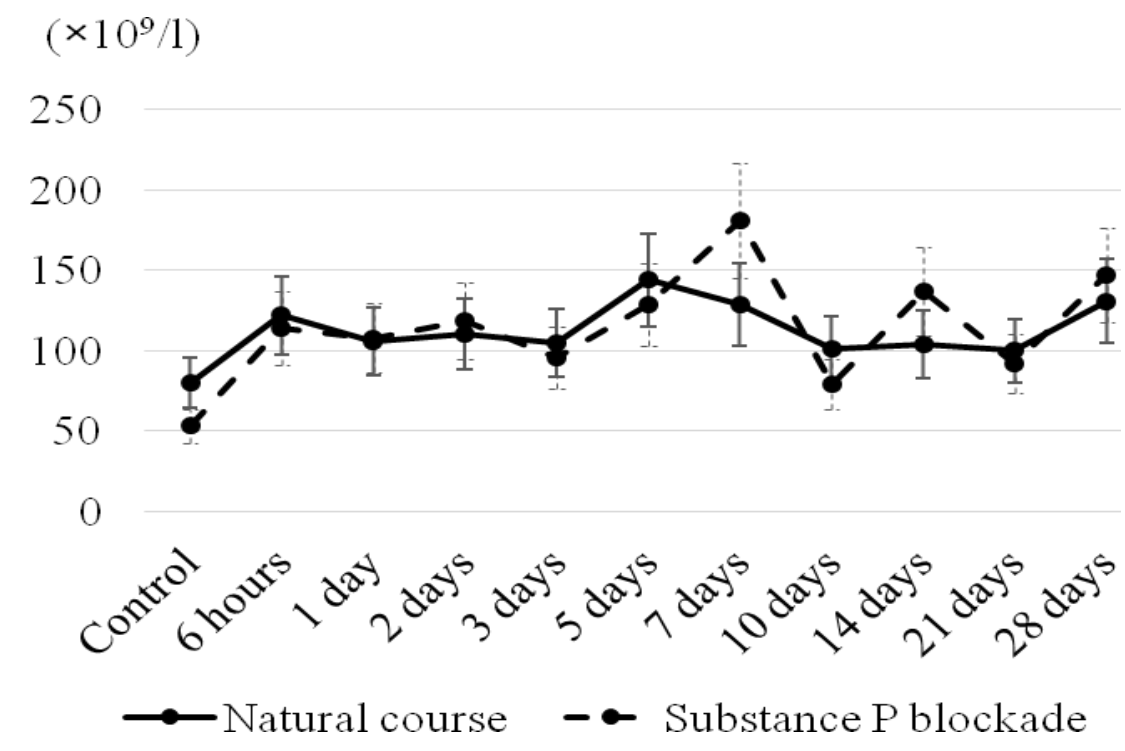

Fig. 1. Myelokaryocytes bone marrow total count myelokaryocytes in the dynamics of carrageenan secondary chronic inflammation $\left(\times 10^{9} / 1\right)$ 
Myelogram data from rats $\left(10^{9} / 1\right)$ in the dynamics of the natural course of carrageenan secondary chronic inflammation

\begin{tabular}{|c|c|c|c|c|c|c|c|c|c|}
\hline \multirow[t]{2}{*}{ Series } & \multirow[t]{2}{*}{ Myelokaryocytes } & \multirow[t]{2}{*}{ Megakaryocytes } & \multirow[t]{2}{*}{ Blasts } & \multicolumn{2}{|c|}{ Neutrophils } & \multirow[t]{2}{*}{ Eosinophils } & \multirow[t]{2}{*}{ Lymphocytes } & \multirow[t]{2}{*}{ Monocytes } & \multirow[t]{2}{*}{ Erythrocyte lineage } \\
\hline & & & & mature & immature & & & & \\
\hline Control & $\begin{array}{c}84.0 \\
{[70.0 ; 91.0]}\end{array}$ & $\begin{array}{c}1.4 \\
{[0.9 ; 1.6]}\end{array}$ & $\begin{array}{c}4.2 \\
{[3.9 ; 5.9]}\end{array}$ & $\begin{array}{c}26.9 \\
{[19.6 ; 29.1]}\end{array}$ & $\begin{array}{c}7.4 \\
{[6.3 ; 9.7]}\end{array}$ & $\begin{array}{c}1.9 \\
{[1.8 ; 2.1]^{\ddagger}}\end{array}$ & $\begin{array}{c}28.5 \\
{[25.6 ; 29.6]^{*}}\end{array}$ & $\begin{array}{c}4.3 \\
{[3.9 ; 4.8]}\end{array}$ & $\begin{array}{c}7.0 \\
{[6.7 ; 10.6]}\end{array}$ \\
\hline 6 hours & $\begin{array}{c}115.5 \\
{[104.0 ; 127.0]}\end{array}$ & $\begin{array}{c}0.6 \\
{[0.5 ; 0.9]^{\dagger}}\end{array}$ & $\begin{array}{c}7.5 \\
{[7.2 ; 8.3]}\end{array}$ & $\begin{array}{c}32.7 \\
{[31.1 ; 34.8]}\end{array}$ & $\begin{array}{c}13.7 \\
{[12.0 ; 18.4]}\end{array}$ & $\begin{array}{c}3.3 \\
{[2.8 ; 4.5]}\end{array}$ & $\begin{array}{c}39.8 \\
{[34.8 ; 45.1]}\end{array}$ & $\begin{array}{c}0.0 \\
{[0.0 ; 0.6]}\end{array}$ & $\begin{array}{c}15.4 \\
{[14.4 ; 21.6]}\end{array}$ \\
\hline 1 day & $\begin{array}{c}99.5 \\
{[92.0 ; 124.0]}\end{array}$ & $\begin{array}{c}3.3 \\
{[1.7 ; 3.7]} \\
\end{array}$ & $\begin{array}{c}6.0 \\
{[4.1 ; 6.2]}\end{array}$ & $\begin{array}{c}25.8 \\
{[22.8 ; 40.8]}\end{array}$ & 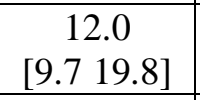 & $\begin{array}{c}3.5 \\
{[1.7 ; 6.1]}\end{array}$ & $\begin{array}{c}33.0 \\
{[25.8 ; 37.7]} \\
\end{array}$ & $\begin{array}{c}0.0 \\
{[0.0 ; 0.5]}\end{array}$ & $\begin{array}{c}14.2 \\
{[13.0 ; 16.3]}\end{array}$ \\
\hline 2 days & $\begin{array}{c}106.0 \\
{[85.0 ; 134.0]}\end{array}$ & $\begin{array}{c}1.3 \\
{[1.1 ; 1.8]}\end{array}$ & $\begin{array}{c}4.9 \\
{[4.4 ; 5.4]}\end{array}$ & $\begin{array}{c}28.8 \\
{[21.3 ; 34.8]^{* \dagger}}\end{array}$ & $\begin{array}{c}11.6 \\
{[9.5 ; 13.8]^{*}}\end{array}$ & $\begin{array}{c}2.2^{+} \\
{[1.4 ; 2.7]}\end{array}$ & $\begin{array}{c}44.7 \\
{[37.7 ; 54.3]^{* * \dagger}}\end{array}$ & 0.0 & $\begin{array}{c}13.6 \\
{[9.4 ; 22.8]}\end{array}$ \\
\hline 3 days & $\begin{array}{c}98.5 \\
{[93.0 ; 118.0]}\end{array}$ & $\begin{array}{c}3.4 \\
{[1.8 ; 5.1]^{*+\dagger}}\end{array}$ & $\begin{array}{c}4.8 \\
{[3.7 ; 5.9]}\end{array}$ & $\begin{array}{c}29.7 \\
{[27.0 ; 31.2]}\end{array}$ & $\begin{array}{c}11.6 \\
{[10.2 ; 14.4]}\end{array}$ & $\begin{array}{c}1.5 \\
{[1.3 ; 1.8]^{*}}\end{array}$ & $\begin{array}{c}35.7 \\
{[31.7 ; 42.9]^{\dagger}}\end{array}$ & $\begin{array}{c}0.0 \\
{[0.0 ; 0.5]}\end{array}$ & $\begin{array}{c}15.9 \\
{[12.1 ; 23.6]}\end{array}$ \\
\hline 5 days & $\begin{array}{c}131.0 \\
{[117 ; 177.0]}\end{array}$ & $\begin{array}{c}3.4 \\
{[2.3 ; 4.4]}\end{array}$ & $\begin{array}{c}8.0 \\
{[4.1 ; 11.9]}\end{array}$ & $\begin{array}{c}40.8 \\
{[34.2 ; 44.8]}\end{array}$ & $\begin{array}{c}18.9 \\
{[14.7 ; 24.0]}\end{array}$ & $\begin{array}{c}2.9 \\
{[2.3 ; 6.7]^{\dagger}}\end{array}$ & $\begin{array}{c}43.9 \\
{[43.4 ; 62.4]^{*}}\end{array}$ & 0.0 & $\begin{array}{c}14.4 \\
{[11.9 ; 16.9]}\end{array}$ \\
\hline 7 days & $\begin{array}{c}130.5 \\
{[114.0 ; 145.0]}\end{array}$ & $\begin{array}{c}2.1 \\
{[1.1 ; 2.5]}\end{array}$ & $\begin{array}{c}7.7 \\
{[7.2 ; 10.3]^{\ddagger}}\end{array}$ & $\begin{array}{c}38.2 \\
{[32.5 ; 41.8]}\end{array}$ & $\begin{array}{c}14.0 \\
{[13.7 ; 17.8]}\end{array}$ & $\begin{array}{c}2.3 \\
{[1.7 ; 2.9]}\end{array}$ & $\begin{array}{c}45.5 \\
{[42.2 ; 46.6]}\end{array}$ & $\begin{array}{c}0.0 \\
{[0.0 ; 2.1]}\end{array}$ & $\begin{array}{c}16.5 \\
{[14.3 ; 18.5]}\end{array}$ \\
\hline 10 days & $\begin{array}{c}98.0 \\
{[88.0 ; 110.0]}\end{array}$ & $\begin{array}{c}1.5 \\
{[1.3 ; 1.7]}\end{array}$ & $\begin{array}{c}5.3 \\
{[4.8 ; 5.8]^{\dagger}} \\
\end{array}$ & $\begin{array}{c}30.8 \\
{[25.7 ; 34.1]^{*}}\end{array}$ & $\begin{array}{c}12.4 \\
{[10.0 ; 14.0]}\end{array}$ & $\begin{array}{c}1.8 \\
{[1.3 ; 2.5]}\end{array}$ & $\begin{array}{c}37.5 \\
{[34.8 ; 40.7]} \\
\end{array}$ & 0.0 & $\begin{array}{c}11.0 \\
{[8.8 ; 13.3]}\end{array}$ \\
\hline 14 days & $\begin{array}{c}95.0 \\
{[70.0 ; 122.0]}\end{array}$ & $\begin{array}{c}1.0 \\
{[0.7 ; 1.8]}\end{array}$ & $\begin{array}{c}6.4 \\
{[4.7 ; 8.3]^{\dagger}}\end{array}$ & $\begin{array}{c}27.2 \\
{[19.8 ; 40.9]}\end{array}$ & $\begin{array}{c}11.1 \\
{[9.4 ; 15.8]}\end{array}$ & $\begin{array}{c}1.5 \\
{[1.0 ; 2.6]}\end{array}$ & $\begin{array}{c}27.4 \\
{[24.5 ; 48.8]}\end{array}$ & $\begin{array}{c}0.1 \\
{[0.0 ; 0.5]}\end{array}$ & $\begin{array}{c}10.6 \\
{[7.2 ; 19.5]}\end{array}$ \\
\hline 21 days & $\begin{array}{c}89.5 \\
{[82.0 ; 114.0]}\end{array}$ & $\begin{array}{c}0.8 \\
{[0.7 ; 1.0]^{*}}\end{array}$ & $\begin{array}{c}6.7 \\
{[4.5 ; 8.6]}\end{array}$ & $\begin{array}{c}25.8 \\
{[22.6 ; 31.9]^{*}}\end{array}$ & $\begin{array}{c}10.9 \\
{[10.0 ; 14.9]}\end{array}$ & $\begin{array}{c}1.1 \\
{[0.5 ; 1.6]^{*}}\end{array}$ & $\begin{array}{c}32.2 \\
{[30.8 ; 45.6]}\end{array}$ & 0.0 & $\begin{array}{c}11.5 \\
{[10.0 ; 16.0]}\end{array}$ \\
\hline 28 days & $\begin{array}{c}132.0 \\
{[109.0 ; 162.0]}\end{array}$ & $\begin{array}{c}0.9 \\
{[0.7 ; 1.2]}\end{array}$ & $\begin{array}{c}9.0 \\
{[4.9 ; 9.4]}\end{array}$ & $\begin{array}{c}37.7 \\
{[31.6 ; 45.4]}\end{array}$ & $\begin{array}{c}14.1 \\
{[9.8 ; 17.8]}\end{array}$ & $\begin{array}{c}2.3 \\
{[1.4 ; 4.1]}\end{array}$ & $\begin{array}{c}49.4 \\
{[41.4 ; 67.2]}\end{array}$ & $\begin{array}{c}8.6 \\
{[6.0 ; 9.4]}\end{array}$ & $\begin{array}{c}9.5 \\
{[6.2 ; 10.1]}\end{array}$ \\
\hline
\end{tabular}

Note. ${ }^{*}$ - the difference in comparison with control is significant at $\mathrm{p}<0.05$; ${ }^{\dagger}$ — the difference in comparison with previous series is

significant at $\mathrm{p}<0.05 ;$ - the difference in comparison with appropriate series on the background of substance $\mathrm{P}$ blockade is significant at $\mathrm{p}<0.05$. 
The wave-like increase is associated first with the primary neutrophil response and later with the activation of hematopoiesis as a reflection of chronic inflammation.

The number of megakaryocytes (Fig. 2): during the natural course increased significantly between series of 6 hours and 1 day ( $p<0.01$ ), between series of 2 and 3 days ( $\mathrm{p}<0.01$ ); against the background of blockade of substance $\mathrm{P}$ decreased significantly between series of 21 and 28 days $(\mathrm{p}=0.04)$.

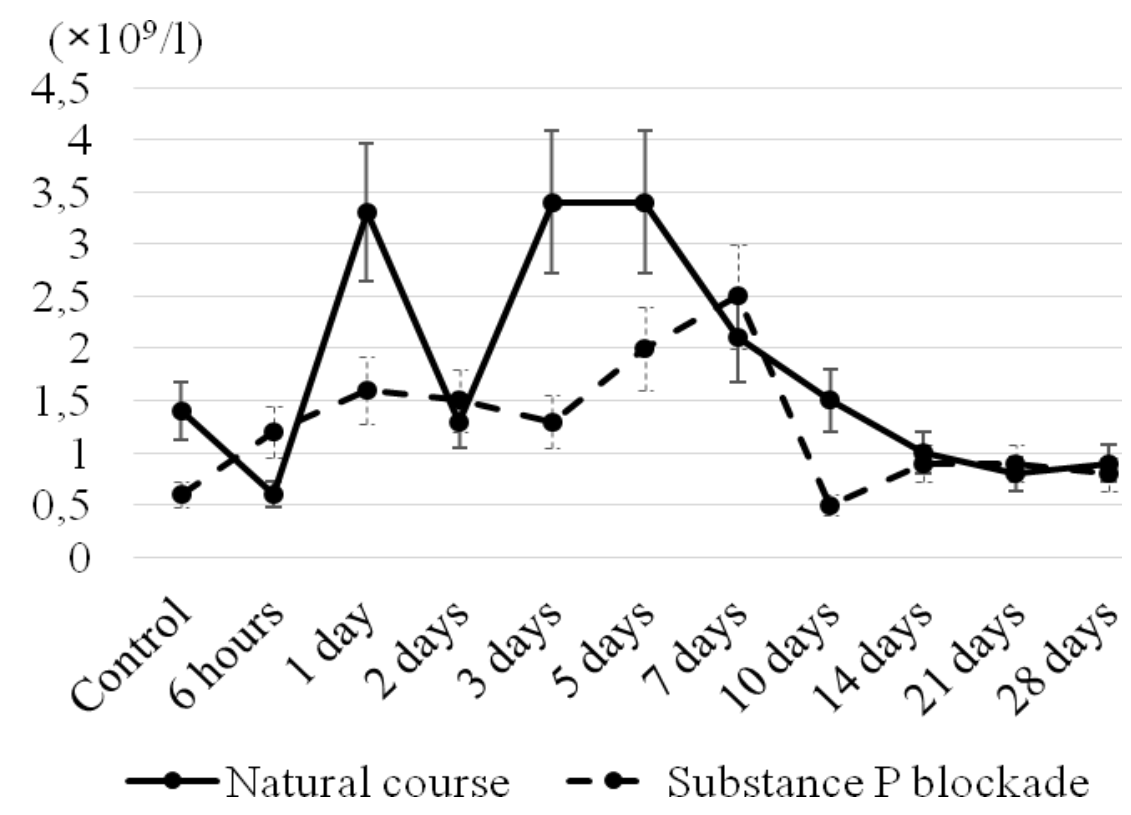

Fig. 2. Megakaryocytes bone marrow count in the dynamics of carrageenan secondary chronic inflammation $\left(\times 10^{9} / 1\right)$

Blasts (Fig. 3): during the natural course of inflammation, their number decreased significantly between series of 7 and 10 days $(p=0.045)$ and increased - between series of 10 and 14 days ( $\mathrm{p}=0.04)$; on the background of blockade of substance P increased significantly between series of 3 and 5 days $(p=0.03)$, decreased - between series of 5 and 7 days $(\mathrm{p}=0.03)$, increased - between series of 21 days and 28 days $(\mathrm{p}<0,01)$.

The number of mature neutrophils (Fig. 4) was not statistically significantly different between consecutive series; on the background of substance P blockade of the difference increased significantly between series 1 and 2 days $(\mathrm{p}=0.01)$ and between series 7 and 10 days $(\mathrm{p}<0.01)$; decreased between series of 10 and 14 days $(\mathrm{p}<0.01)$. 


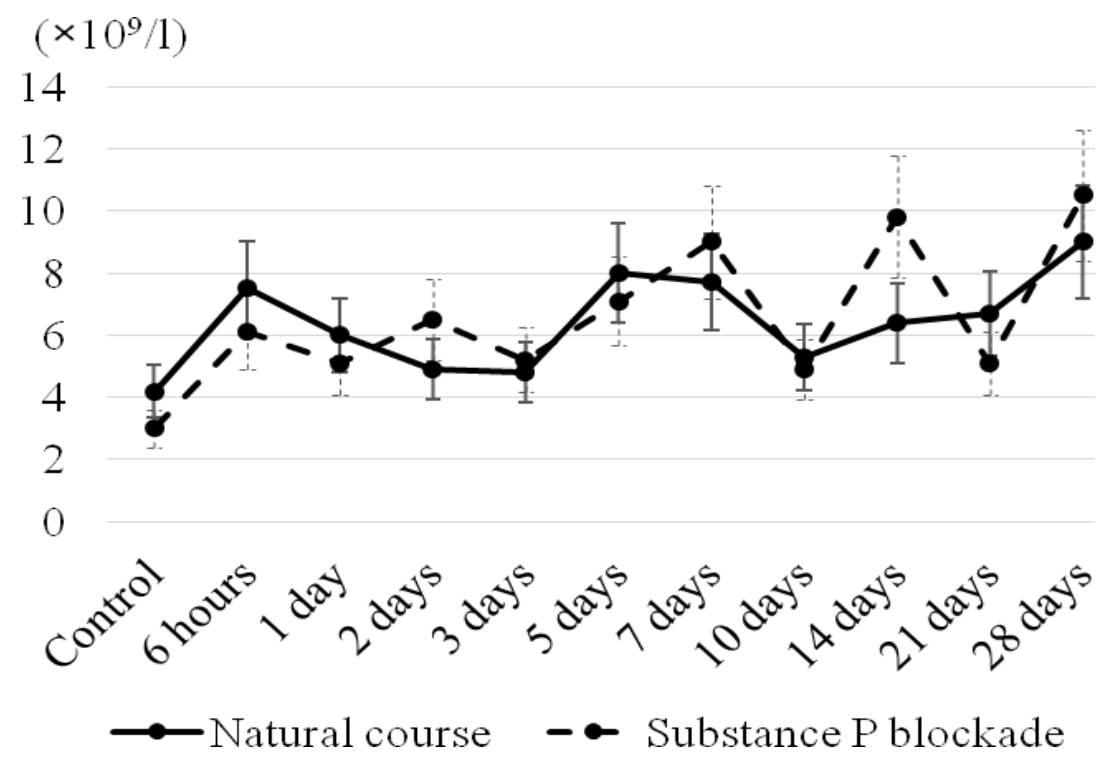

Fig. 3. Blasts bone marrow count in the dynamics of carrageenan secondary chronic inflammation $\left(\times 10^{9} / \mathrm{l}\right)$

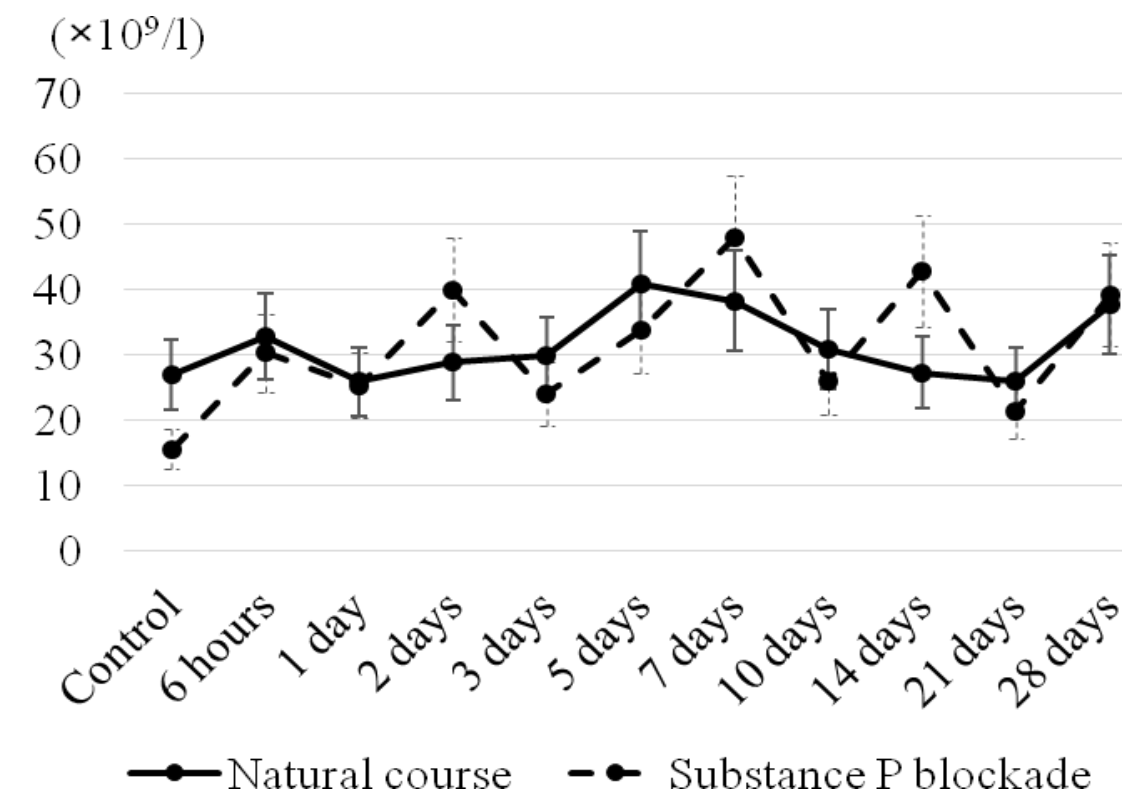

Fig. 4. Mature neutrophils bone marrow count in the dynamics of carrageenan secondary chronic inflammation $\left(\times 10^{9} / \mathrm{l}\right)$

The dynamics of fluctuations in the number of immature neutrophils (Fig. 5) may indicate the phases of their enhanced exit from the heart rate into the circulating blood, hyperplasia of the red bone marrow, chronic inflammation. 


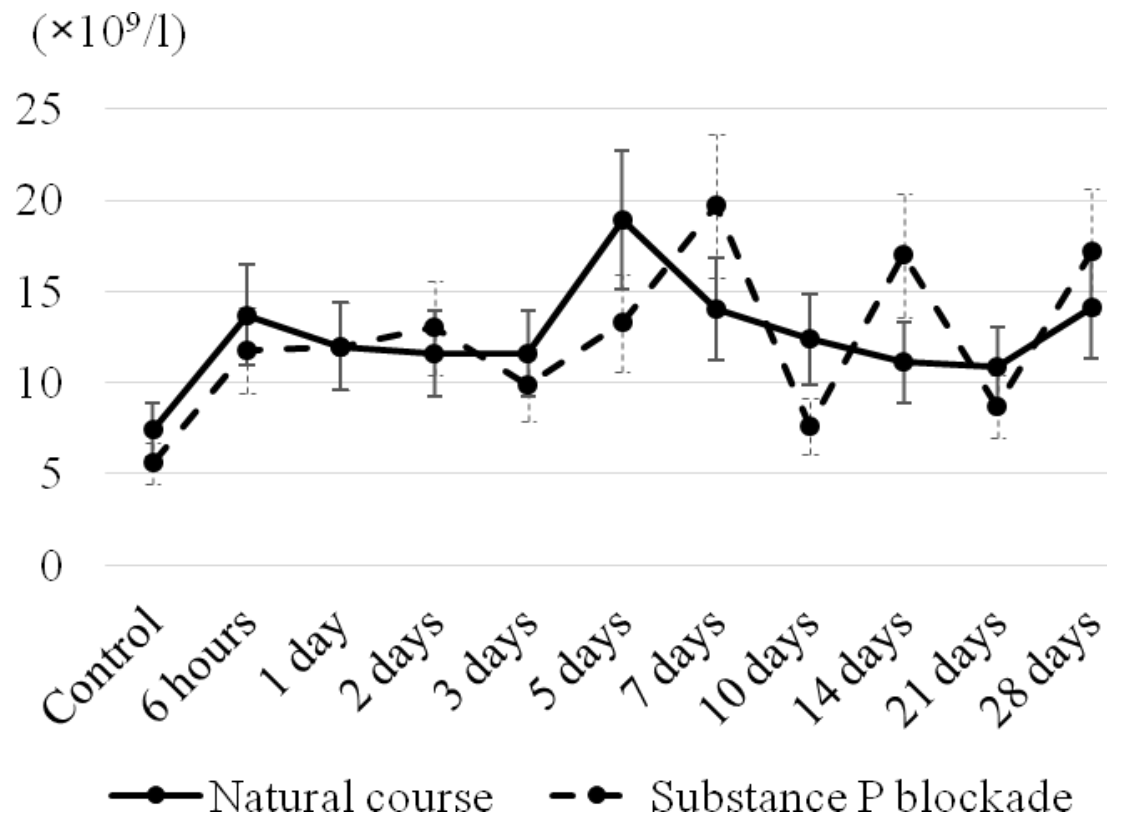

Fig. 5. Immature neutrophils bone marrow count in the dynamics of carrageenan secondary chronic inflammation $\left(\times 10^{9} / 1\right)$

Thus, the number of immature neutrophils in the natural course of inflammation decreased significantly between series of 1 and 2 days $(p=0.045)$; on the background of blockade of substance $P$ increased significantly between series of 10 and 14 days $(p=0.045)$, 21 days and 28 days $(\mathrm{p}=0.04)$; significantly decreased between series of 7 and 10 days $(\mathrm{p}=0.03)$.

Eosinophils (Fig. 6): during the natural course, their number increased significantly between series of 3 and 5 days $(\mathrm{p}=0.03)$; on the background of substance $\mathrm{P}$ blockade increased significantly between series of 6 hours and 1 day $(p=0.045)$, decreased between series of 1 day and 2 days $(\mathrm{p}=0.03)$.

The number of lymphocytes (Fig. 7): during the natural course increased significantly between series 1 day and 2 days $(p=0.03)$, decreased between series 2 and 3 days $(p=0.03)$; o the background of blockade of substance P increased significantly between series of 2 and 3 days $(\mathrm{p}=0.03)$, decreased between series of 3 and 5 days $(\mathrm{p}<0.01)$, then increased between series of 5 and 7 days $(\mathrm{p}<0,01)$. 


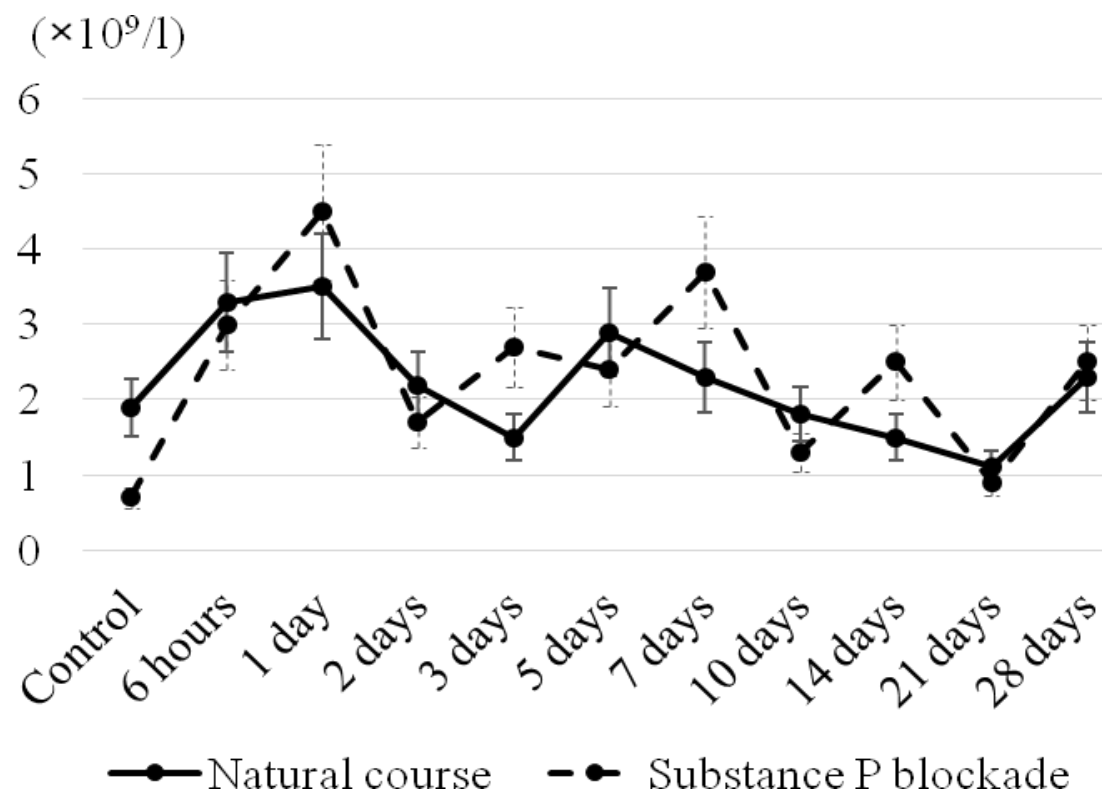

Fig. 6. Eosinophils bone marrow count in the dynamics of carrageenan secondary chronic inflammation $\left(\times 10^{9} / 1\right)$

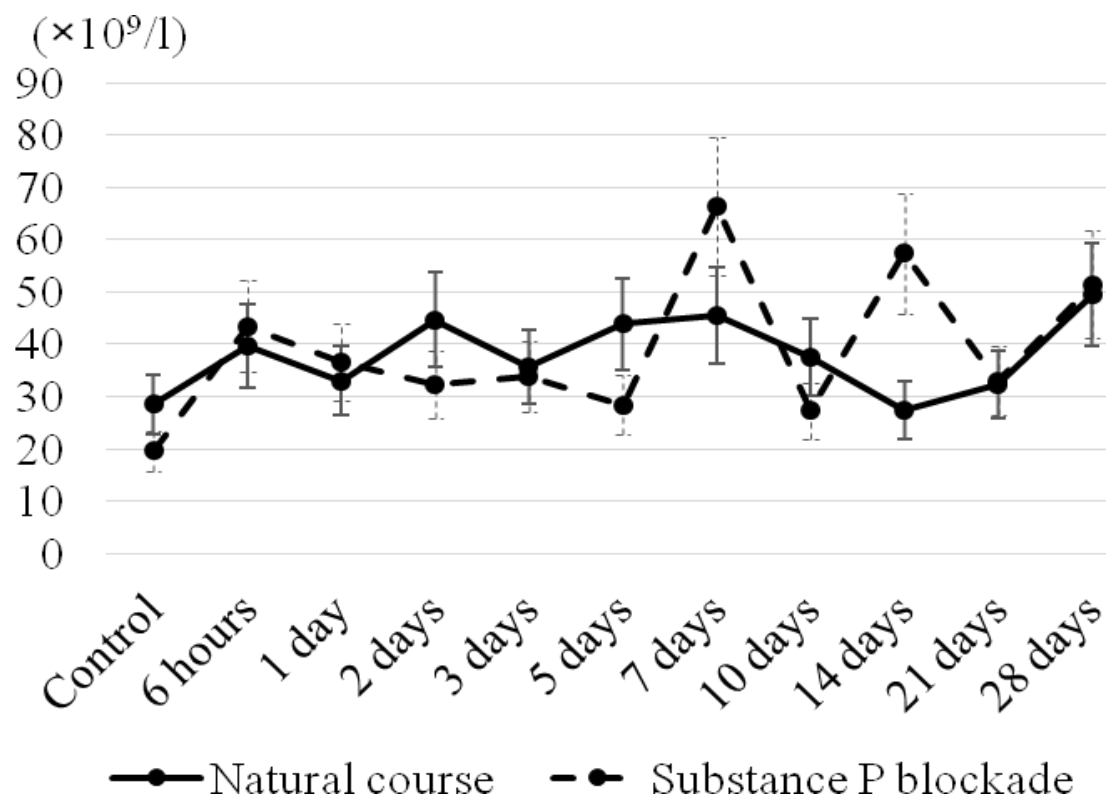

Fig. 7. Lymphocytes bone marrow count in the dynamics of carrageenan secondary chronic inflammation $\left(\times 10^{9} / 1\right)$

The number of monocytes (Fig. 8) in the natural course of inflammation increased significantly by 28 days ( $<<0.01$ ), fluctuating in other series at low values. 


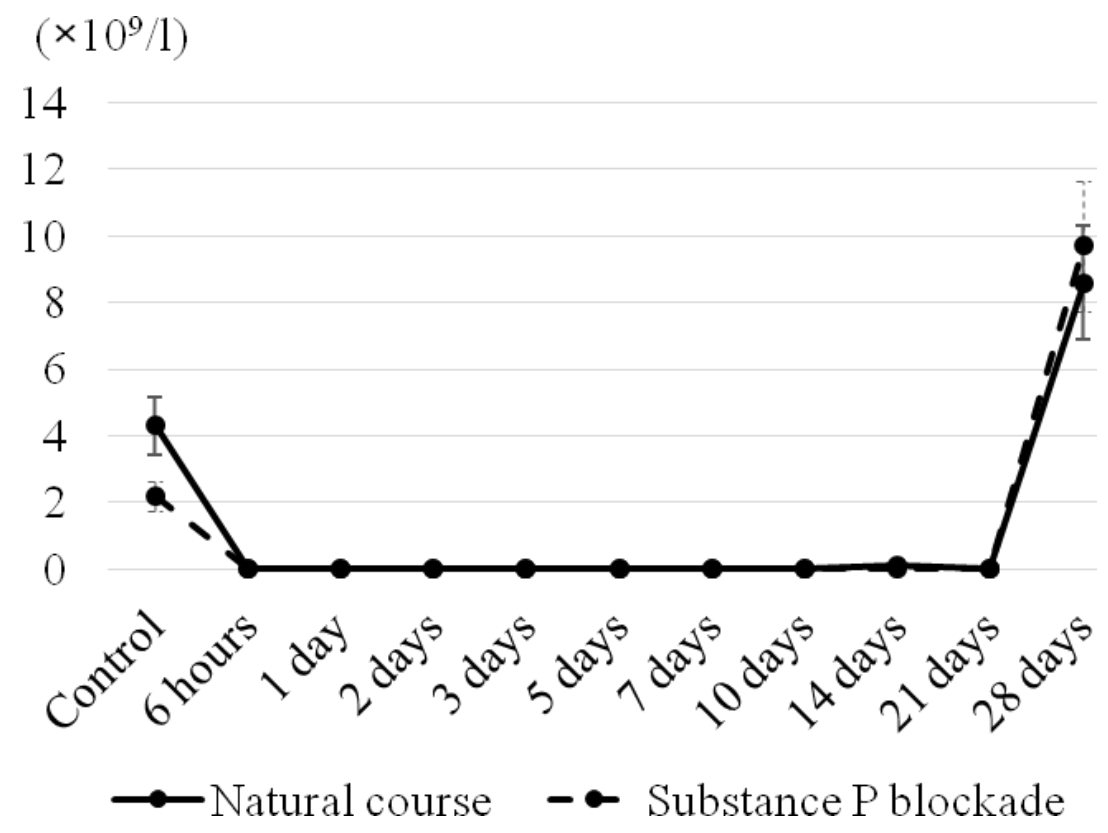

Fig. 8. Monocytes bone marrow count in the dynamics of carrageenan secondary chronic inflammation $\left(\times 10^{9} / 1\right)$

There were changes in the erythrocyte hematopoiesis (Fig. 9).

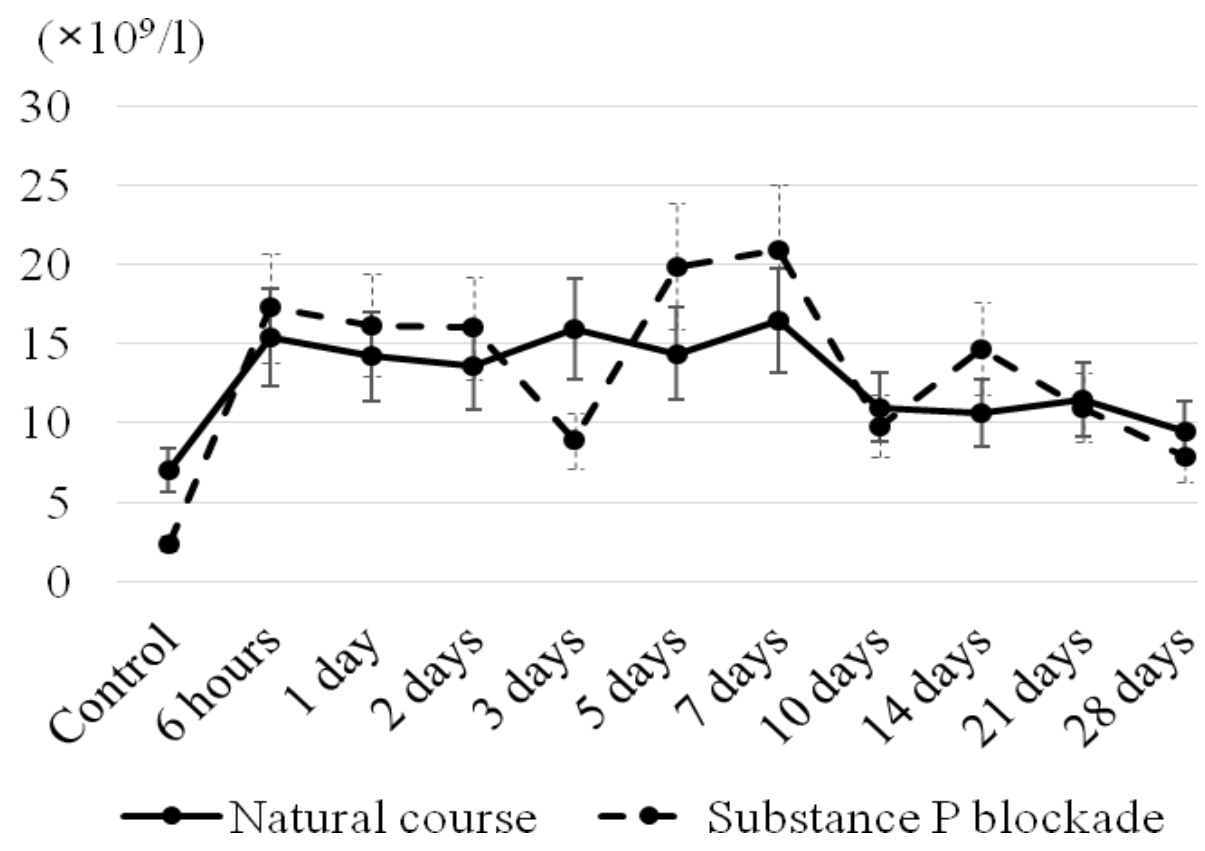

Fig. 9. Erythrocyte lineage cells bone marrow count in the dynamics of carrageenan secondary chronic inflammation $\left(\times 10^{9} / 1\right)$

The count of relevant components of cell subpopulations: in the natural course of the early stages of inflammation was not statistically significant between series; significantly 
increased between series of 10 days and 14 days $(p=0.03), 14$ days and 21 days $(p=0.03)$ and fluctuated in different directions between series of 21 and 28 days, decreasing $(p=0.03)$ and increasing between series of 21 and 28 days ( $p<0.01)$; against the background of blockade of substance P significantly increased between series of 6 hours and 1 day $(\mathrm{p}=0.049)$, decreased between series of 1 and 2 days $(\mathrm{p}=0.02$ and $\mathrm{p}=0.045)$, between series of 2 and 3 days decreased $(p<0.01)$ and increased $(p=0.045)$, increased between series 3 and 5 days $(\mathrm{p}<0.01)$, increased between series 21 and 28 days $(\mathrm{p}<0.01)$.

Compared with the intact control of the natural course of inflammation, the following phases are described: at 6 hours of inflammation - mainly neutrophil reaction; on the 2nd day - lymphocytic and monocytic-macrophage components of red bone marrow hyperplasia are sometimes added to the signs of increased production and maturation of neutrophil leukocytes.

Thus, in the natural course compared with intact control, a natural difference was found: in 6 hours - more immature neutrophils $(p=0.02)$, less mature neutrophils $(p=0.01)$, megakaryocytes $(\mathrm{p}=0.02)$, subpopulations erythroid link $(\mathrm{p}=0.01)$; in 1 day $-\mathrm{a}$ smaller number of erythroid sprout cells $(\mathrm{p}=0.01)$; on the 2 nd day - a larger number of lymphocytes $(p=0.02)$; fewer mature neutrophils $(p=0.02)$, erythroid subpopulation cells $(p<0.01)$; on the 3rd day - a larger number of megakaryocytes $(p=0.03)$; fewer eosinophils $(p=0.02)$, erythroid cells ( $\mathrm{p}<0.01$ ); on the 5th day - a larger number of immature neutrophils $(\mathrm{p}=0.02$; $p=0.03)$; smaller number of erythroid cells $(p<0,01)$; on day $7-$ a smaller number of the erythroid component of the red bone marrow ( $p<0,01)$; for 10 days - more immature neutrophils $(\mathrm{p}=0.04)$; smaller number of erythroid representatives $(\mathrm{p}=0.02 ; \mathrm{p}<0.01)$; on the 14th day - a smaller number of erythroid cells $(p=0.03 ; p<0.01)$; on the 21 st day $-a$ larger number of immature neutrophils $(p=0.02)$; smaller number of mature neutrophils $(p=0.02)$, eosinophils $(p=0.04)$, megakaryocytes $(p=0.02)$; on day $28-$ a greater number of monocytes $(\mathrm{p}<0,01)$ and a smaller number of erythroid cells $(\mathrm{p}=0,03)$.

On the background of substance $\mathrm{P}$ blockade, the course of inflammation was characterized by certain features of the myelogram data, which mainly consisted of a less intense neutrophilic reaction and the development of the lymphocyte component at earlier stages of inflammation (Table 2).

Thus, in the blockade of substance $\mathrm{P}$, in comparison with the series of natural course of carrageenan secondary-chronic inflammation, different rates of neutrophil release into the circulating blood, activation of hematopoiesis and chronic inflammation attract attention. 
Myelogram data from rats $\left(10^{9} / 1\right)$ in the dynamics of secondary inflammation on the background of substance $P$ blockade

\begin{tabular}{|c|c|c|c|c|c|c|c|c|c|}
\hline \multirow[t]{2}{*}{ Series } & \multirow[t]{2}{*}{ Myelokaryocytes } & \multirow[t]{2}{*}{ Megakaryocytes } & \multirow[t]{2}{*}{ Blasts } & \multicolumn{2}{|c|}{ Neutrophils } & \multirow[t]{2}{*}{ Eosinophils } & \multirow[t]{2}{*}{ Lymphocytes } & \multirow[t]{2}{*}{ Monocytes } & \multirow{2}{*}{$\begin{array}{c}\text { Erythrocyte } \\
\text { lineage }\end{array}$} \\
\hline & & & & зрілі & незрілі & & & & \\
\hline Control & $\begin{array}{c}50.0 \\
{[28.0 ; 72.0]}\end{array}$ & $\begin{array}{c}0.6 \\
{[0.2 ; 0.8]}\end{array}$ & $\begin{array}{c}3.0 \\
{[1.5 ; 3.8]}\end{array}$ & $\begin{array}{c}15.5 \\
{[8.3 ; 23.4]}\end{array}$ & $\begin{array}{c}5.6 \\
{[3.4 ; 6.5]}\end{array}$ & $\begin{array}{c}0.7 \\
{[0.3 ; 1.4]^{*}}\end{array}$ & $\begin{array}{c}19.6 \\
{[11.2 ; 28.4]^{\ddagger}}\end{array}$ & $\begin{array}{c}2.2 \\
{[1.3 ; 3.7]}\end{array}$ & $\begin{array}{c}2.4 \\
{[1.8 ; 4.7]}\end{array}$ \\
\hline 6 hours & $\begin{array}{c}111.0 \\
{[90.0 ; 126.0]}\end{array}$ & $\begin{array}{c}1.2 \\
{[0.8 ; 1.8]^{*}}\end{array}$ & $\begin{array}{c}6.1 \\
{[5.7 ; 6.7]}\end{array}$ & $\begin{array}{c}30.2 \\
{[23.8 ; 34.0]^{*}}\end{array}$ & $\begin{array}{c}11.8 \\
{[10.6 ; 12.0]^{*}}\end{array}$ & $\begin{array}{c}3.0 \\
{[2.5 ; 3.7]} \\
\end{array}$ & $\begin{array}{c}43.5 \\
{[37.4 ; 52.3]^{\ddagger}}\end{array}$ & 0 & $\begin{array}{c}17.3 \\
{[11.0 ; 20.3]}\end{array}$ \\
\hline 1 day & $\begin{array}{c}98.0 \\
{[88.0 ; 142.0]}\end{array}$ & $\begin{array}{c}1.6 \\
{[1.4 ; 1.8]^{*}}\end{array}$ & $\begin{array}{c}5.1 \\
{[4.3 ; 6.6]}\end{array}$ & $\begin{array}{c}25.3 \\
{[10.9 ; 32.3]^{*}}\end{array}$ & $\begin{array}{c}12.0 \\
{[10.6 ; 16.0]} \\
\end{array}$ & $\begin{array}{c}4.5 \\
{[3.1 ; 5.7]^{* \dagger}}\end{array}$ & $\begin{array}{c}36.7 \\
{[31.5 ; 46.2]}\end{array}$ & $\begin{array}{c}0.0 \\
{[0.0 ; 0.8]}\end{array}$ & $\begin{array}{c}16.2 \\
{[14.8 ; 22.0]}\end{array}$ \\
\hline 2 days & $\begin{array}{c}107.0 \\
{[98.0 ; 123.0]}\end{array}$ & $\begin{array}{c}1.5 \\
{[1.4 ; 1.8]}\end{array}$ & $\begin{array}{c}6.5 \\
{[5.0 ; 6.9]}\end{array}$ & $\begin{array}{c}39.9 \\
{[29.9 ; 47.9]^{* \dagger}}\end{array}$ & $\begin{array}{c}13.0 \\
{[10.6 ; 15.2]}\end{array}$ & $\begin{array}{c}1.7 \\
{[1.0 ; 3.4]^{\dagger}}\end{array}$ & $\begin{array}{c}32.2 \\
{[29.6 ; 36.3]^{* \ddagger}}\end{array}$ & 0 & $\begin{array}{c}16.0 \\
{[13.3 ; 22.4]}\end{array}$ \\
\hline 3 days & $\begin{array}{c}85.0 \\
{[68.0 ; 121.0]}\end{array}$ & $\begin{array}{c}1.3 \\
{[0.8 ; 1.5]^{*}}\end{array}$ & $\begin{array}{c}5.2 \\
{[2.4 ; 5.5]}\end{array}$ & $\begin{array}{c}24.0 \\
{[18.7 ; 35.1]}\end{array}$ & $\begin{array}{c}9.9 \\
{[7.5 ; 14.5]}\end{array}$ & $\begin{array}{c}2.7 \\
{[1.0 ; 3.7]}\end{array}$ & $\begin{array}{c}33.9 \\
{[27.8 ; 51.4]}\end{array}$ & 0 & $\begin{array}{c}8.9 \\
{[8.6 ; 9.7]}\end{array}$ \\
\hline 5 days & $\begin{array}{c}106.5 \\
{[97.0 ; 117.0]}\end{array}$ & $\begin{array}{c}2.0 \\
{[1.3 ; 3.4]}\end{array}$ & $\begin{array}{c}7.1 \\
{[6.8 ; 9.4]^{\dagger}}\end{array}$ & $\begin{array}{c}33.8 \\
{[31.6 ; 36.5]}\end{array}$ & $\begin{array}{c}13.3 \\
{[11.0 ; 15.8]}\end{array}$ & $\begin{array}{c}2.4 \\
{[1.9 ; 2.8]^{*}}\end{array}$ & $\begin{array}{c}28.4 \\
{[24.0 ; 34.5]^{*+\dagger}}\end{array}$ & $\begin{array}{c}0.0 \\
{[0.0 ; 0.5]}\end{array}$ & $\begin{array}{c}19.9 \\
{[14.9 ; 28.8]}\end{array}$ \\
\hline 7 days & $\begin{array}{c}175.5 \\
{[149.0 ; 200.0]}\end{array}$ & $\begin{array}{c}2.5 \\
{[1.8 ; 4.3]}\end{array}$ & $\begin{array}{c}9.0 \\
{[7.6 ; 10.6]^{\dagger \dagger}}\end{array}$ & $\begin{array}{c}47.9 \\
{[42.5 ; 57.0]}\end{array}$ & $\begin{array}{c}19.7 \\
{[17.8 ; 25.5]}\end{array}$ & $\begin{array}{c}3.7 \\
{[2.5 ; 4.7]}\end{array}$ & $\begin{array}{c}66.4 \\
{[59.2 ; 77.0]^{\dagger}}\end{array}$ & 0 & $\begin{array}{c}20.9 \\
{[19.4 ; 21.9]}\end{array}$ \\
\hline 10 days & $\begin{array}{c}77.5 \\
{[57.0 ; 114.0]}\end{array}$ & $\begin{array}{c}0.5 \\
{[0.3 ; 1.2]} \\
\end{array}$ & $\begin{array}{c}4.9 \\
{[2.9 ; 6.7]} \\
\end{array}$ & $\begin{array}{c}26.0 \\
{[20.2 ; 33.9]^{* \dagger}}\end{array}$ & $\begin{array}{c}7.6 \\
{[5.9 ; 12.0]} \\
\end{array}$ & $\begin{array}{c}1.3 \\
{[0.9 ; 1.8]}\end{array}$ & $\begin{array}{c}27.3 \\
{[20.3 ; 39.3]} \\
\end{array}$ & 0 & $\begin{array}{c}9.8 \\
{[6.2 ; 13.4]} \\
\end{array}$ \\
\hline 14 days & $\begin{array}{c}150.0 \\
{[96.0 ; 154.0]}\end{array}$ & $\begin{array}{c}0.9 \\
{[0.8 ; 1.4]}\end{array}$ & $\begin{array}{c}9.8 \\
{[5.3 ; 11.8]} \\
\end{array}$ & $\begin{array}{c}42.7 \\
{[30.7 ; 48.5]} \\
\end{array}$ & $\begin{array}{c}17.0 \\
{[11.9 ; 18.2]} \\
\end{array}$ & $\begin{array}{c}2.5 \\
{[0.7 ; 2.9]}\end{array}$ & $\begin{array}{c}57.4 \\
{[33.0 ; 63.8]}\end{array}$ & 0 & $\begin{array}{c}14.7 \\
{[13.1 ; 19.2]}\end{array}$ \\
\hline 21 days & $\begin{array}{c}82.0 \\
{[62.0 ; 97.0]}\end{array}$ & $\begin{array}{c}0.9 \\
{[0.5 ; 1.1]}\end{array}$ & $\begin{array}{c}5.1 \\
{[2.5 ; 6.3]}\end{array}$ & $\begin{array}{c}21.3 \\
{[16.7 ; 30.6]}\end{array}$ & $\begin{array}{c}8.7 \\
{[6.8 ; 10.7]}\end{array}$ & $\begin{array}{c}0.9 \\
{[0.5 ; 1.1]}\end{array}$ & $\begin{array}{c}33.0 \\
{[28.2 ; 36.4]}\end{array}$ & 0 & $\begin{array}{c}11.0 \\
{[6.7 ; 12.7]}\end{array}$ \\
\hline 28 days & $\begin{array}{c}142.5 \\
{[128.0 ; 156.0]}\end{array}$ & $\begin{array}{c}0.8 \\
{[0.8 ; 1.0]^{\dagger}}\end{array}$ & $\begin{array}{c}10.5 \\
{[9.4 ; 11.3]^{* \dagger}}\end{array}$ & $\begin{array}{c}39.2 \\
{[38.9 ; 42.1]}\end{array}$ & $\begin{array}{c}17.2 \\
{[14.2 ; 24.2]}\end{array}$ & $\begin{array}{c}2.5 \\
{[2.3 ; 3.5]}\end{array}$ & $\begin{array}{c}51.4 \\
{[44.2 ; 62.4]}\end{array}$ & $\begin{array}{c}9.7 \\
{[9.1 ; 10.9]}\end{array}$ & $\begin{array}{c}7.9 \\
{[6.5 ; 8.7]} \\
\end{array}$ \\
\hline
\end{tabular}

Note. ${ }^{*}$ - the difference in comparison with control is significant at $\mathrm{p}<0.05 ;{ }^{\dagger}$ - the difference in comparison with previous series is significant at $\mathrm{p}<0.05 ;$ - the difference in comparison with appropriate series on the background of natural course of inflammation is significant at $\mathrm{p}<0.05$. 
The following comparative results were obtained: in the control series - a larger number of lymphocytes $(p=0.045)$; less eosinophils $(p=0.045)$, erythroid cells $(p=0.03)$; in series of 6 hours - a larger number of lymphocytes $(\mathrm{p}<0,01)$; smaller number of mature neutrophils ( $\mathrm{p}=0.03$ ); in series of 1 day - no statistically significant differences were found; in series of 2 days - a larger number of mature neutrophils $(p=0.02 ; p=0.045)$; fewer lymphocytes ( $p<0.01)$; in series of 3 days - a larger number of erythroid cells $(p=0.045)$.

There was smaller number of megakaryocytes $(\mathrm{p}=0.045)$, subpopulations of erythrocyte series $(\mathrm{p}=0.02)$; in series of 5 days - a smaller number of lymphocytes $(p<0,01)$; in series of 7 days - a smaller number of blast cells $(p=0.04)$; in series of 10 days - a larger number of mature neutrophils $(\mathrm{p}=0.03)$; smaller number of immature neutrophils $(\mathrm{p}=0.02)$; in series of 14 days - no statistically significant differences were found; in series of 21 days - a larger number of megakaryocytes $(p=0.045)$; in series of 28 days - a larger number of erythrocyte cells $(\mathrm{p}=0.02)$.

Compared with the control series with the introduction of the drug, in the red bone marrow in the dynamics of carrageenan secondary chronic inflammation on the background of blockade of substance $\mathrm{P}$, the following comparative results were obtained.

A difference was found: in 6 hours - a smaller number of mature neutrophils $(p=0.01)$, erythroid cells $(p<0.01)$; for 1 day - a larger number of eosinophils $(p=0.01)$, megakaryocytes $(\mathrm{p}=0.045)$, subpopulations of erythroid cells $(\mathrm{p}=0.04 ; \mathrm{p}=0.02 ; \mathrm{p}<0.01)$; fewer mature neutrophils ( $p=0.01$ ); on the 2 nd day - a larger number of cells of the erythroid series $(\mathrm{p}=0.02)$; less lymphocytes $(\mathrm{p}=0.04)$, erythroid subpopulations $(\mathrm{p}<0.01)$; on day 3 a smaller number of erythroid cells $(\mathrm{p}<0,01)$; on the 5th day - a larger number of eosinophils $(p=0.02)$, erythroid subpopulation $(p=0.02)$; fewer lymphocytes $(p<0.01)$, erythroid cells $(\mathrm{p}<0.01)$; on day 7 - a smaller number of mature neutrophils $(\mathrm{p}=0.046)$, erythroid cells $(\mathrm{p}<0.01)$; for 10 days - a smaller number of immature neutrophils $(p=0,045)$, subpopulations of erythroid cells $(\mathrm{p}<0,01)$; on the 14th day - a smaller number of mature neutrophils $(\mathrm{p}=0.03)$, erythroid subpopulations $(\mathrm{p}=0.02 ; \mathrm{p}<0.01)$; on the 21 st day $-\mathrm{a}$ larger number of erythroid cells $(\mathrm{p}=0.01 ; \mathrm{p}<0.01)$; on day $28-\mathrm{a}$ larger number of blast cells $(\mathrm{p}=0.03)$.

Thus, the peculiarities of bone marrow hematopoiesis in carrageenan secondarychronic inflammation against the background of blockade of substance $\mathrm{P}$, which are signs of a less pronounced inflammatory reaction. In the early stages - 6 hours, 2 days - a smaller $(\mathrm{p}<0.05)$ number of neutrophils (cells involved in the implementation of mostly nonspecific reactions), megakaryocytes (which, in addition to inflammation, is a marker of the blood 
coagulation system). This fits well with the concept of linking the blockade of NK1 receptors of substance $\mathrm{P}$ and reducing its activating effect on hematopoiesis [14, 15].

The higher content of the cell population of lympoid germ of hematopoiesis, which is found at different stages of inflammation lasting up to 5 days, can be interpreted as a compensatory response of the immune system with redistribution of subpopulations of effector cells from nonspecific immunity in favor of specific.

\section{Conclusions:}

1. Features of bone marrow hematopoiesis in carrageenan secondary chronic inflammation on the background of its suppression by administration of the NKR-1 blocker substance $\mathrm{P}$ is a smaller $(\mathrm{p}<0,05)$ in the early stages number of cells involved in the implementation of mostly nonspecific immunoinflammatory reactions and markers blood coagulation system.

2. A higher content of the cell population of the lymphocytic germ of hematopoiesis on the background of blockade against the background of blockade of substance P.

3. Prospects for further research are the study of integral marker role of bone marrow, tissue-cellular reactions in situ, peripheral blood, cytokines and other parameters of inflammation on the background of substance P blockage.

\section{References}

1. Navratilova E. Substance P and Inflammatory Pain: Getting It Wrong and Right Simultaneously / E. Navratilova, F. Porreca // Neuron. - 2019. — Vol. 101, No. 3. — P. 353-355. — doi: 10.1016/j.neuron.2019.01.034.

2. Tachykinins and tachykinin receptors: a growing family / J. N. Pennefather, A. Lecci, M. L. Candenas [et al.] // Life Sci. — 2004. — Vol. 74, No. 12. — P. 1445-1663.

3. Substance $\mathrm{P}$ and neurotensin in the limbic system: Their roles in reinforcement and memory consolidation / L. Lénárd, K. László, E. Kertes [et al.] // Neurosci. Biobehav. Rev. — 2018. — Vol. 85. — P. 1-20 - doi: 10.1016/j.neubiorev.2017.09.003.

4. Suvas S. Role of substance P neuropeptide in inflammation, wound healing, and tissue homeostasis // J. Immunol. - 2017. — Vol. 199, No. 5. — P. 1543-1552.

5. Euler U. S. An unidentified depressor substance in certain tissue extracts / U.S. Euler, J.H Gaddum // J. Physiol. — 1931. — Vol. 72. — P. 74-87.

6. Majkowska-Pilip A. The Significance of NK1 Receptor Ligands and Their Application in Targeted Radionuclide Tumour Therapy / A. Majkowska-Pilip, P. K. Halik, E. Gniazdowska // Pharmaceutics. - 2019. - Vol. 11, No. 9. - pii: E443 - doi: 10.3390/pharmaceutics11090443. 
7. Cough hypersensitivity in patients with obstructive sleep apnea hypopnea syndrome / C. Shi, S. Liang, X. Xu [et al.] // Sleep Breath. — 2018. — doi: 10.1007/s11325018-1641-7.

8. Reciprocal regulation of substance $\mathrm{P}$ and $\mathrm{IL}-12 / \mathrm{IL}-23$ and the associated cytokines, IFN $\gamma / \mathrm{IL}-17$ : a perspective on the relevance of this interaction to multiple sclerosis / J. Vilisaar, K. Kawabe, M. Braitch [et al.] // J. Neuroimmune Pharmacol. — 2015. —Vol. 10, No. 3. - P. 457-467.

9. TRPV1 and TRPA1 in cutaneous neurogenic and chronic inflammation: proinflammatory response induced by their activation and their sensitization / O. Gouin, L. L’Herondelle, N. Lebonva [et al.] // Prot. Cell. — 2017. — Vol. 8, No. 9. - P. 644-661.

10. Klymenko N. A. Role of inflammation in pathology // General pathology and pathologic physiology. - 2010. - Vol. 5, No. 2. - P. 20-21.

11. Klymenko N. A. Substantiation of the model of chronic (secondary) inflammation / N. A. Klymenko, S. V. Tatarko, A. N. Shevchenko [et al.] // Experimental and Clinical Medicine. - 2007. - No. 2. - P. 12-17.

12. An FDA approved neurokinin-1 receptor antagonist is effective in reducing intraabdominal adhesions when administered intraperitoneally, but not orally / R. Lim, J. M. Morrill, S. G. Prushik [et al.] // J. Gastrointest. Surg. — 2008. — Vol. 12. — P. 1754-1761. — doi: 10.1007/s11605-008-0634-4.

13. Klymenko N. A. Hematologic mechanisms of inflammation chronization / N. A. Klymenko, A. N. Shevchenko. — Kharkiv, 2010. - 88 p.

14. Stead R. H. Neuropeptide regulation of mucosal immunity / R. H. Stead, J. Bienenstock, A. M. Stanisz // Immunol. Rev. - 1987. - Vol. 100. - P. 333-359. doi: 10.1111/j.1600-065x.1987.tb00538.x

15. Noradrenergic and peptidergic innervation of lymphoid organs / S. Y. Felten, D. L. Felten, D. L. Bellinger, J. A. Olschowka // Chem. Immunol. — 1992. — Vol. 52. — P. 25-48. 